
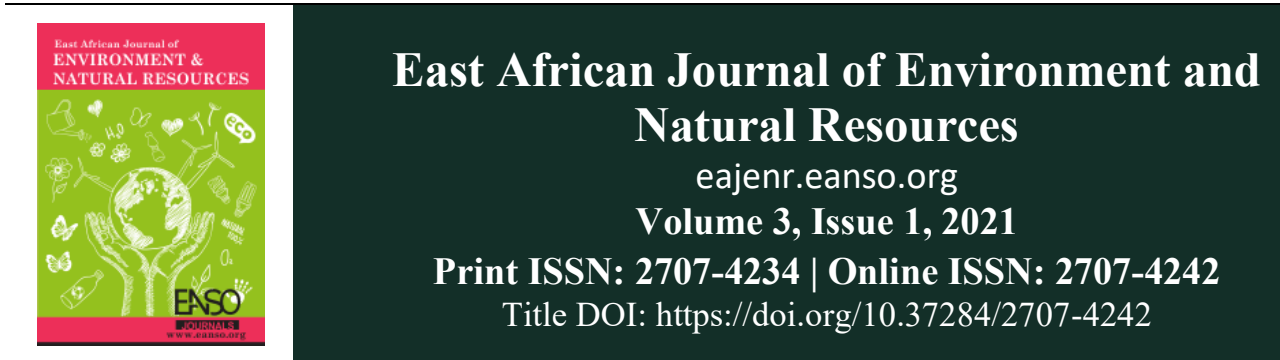

Original Article

\title{
The Geology of Silali Basin (Kenya) as an Extra-Terrestrial Impact Crater (ETIC)
}

\author{
Loice J. Kipkiror, $P h D^{1^{*}}$, Bernard Kipsang Rop, $P h D^{2} \&$ Elias Kerukaba Ucakuwun, PhD ${ }^{3}$ \\ ${ }^{1}$ Department of Humanities and Social Sciences, University of Kabianga, P. O. Box 2030 - 20200, Kericho, Kenya. \\ ${ }^{2}$ Department of Mining, Materials and Petroleum Engineering, Jomo Kenyatta University of Agriculture and Technology, P. O. \\ Box 62000 - 00200, Nairobi, Kenya. \\ ${ }^{3}$ University of Eldoret, P. O. Box $1125-30100$, Eldoret, Kenya. \\ ${ }^{*}$ Author for Correspondence email: jemencho@gmail.com.
}

Article DOI: https://doi.org/10.37284/eajenr.3.1.278

\section{Date Published: ABSTRACT}

22 February 2021 Certain rocks, rock minerals and rock formations have come to be associated with ETICs (Extra-terrestrial Impact Craters). An extra-terrestrial impact crater is a crater

Keywords: that is formed by an extra-terrestrial impact event whereby a heavenly body (a meteor, comet, or asteroid) hits the earth's surface and creates a crater; before it cools on the Geology, earth's surface as a meteorite or completely gets squashed by the thermodynamics of ETIC, space transit. The crater created can be dry or filled with water and may be a simple

Extra-Terrestrial Impact,

Silali Basin. crater or a complex one, also denoted as a basin. The objective of this paper is to describe the geology of the Silali basin as an Extra-Terrestrial Impact Crater (ETIC), highlight the importance of some of its ETIC rocks and explain the formation of the Silali basin resulting from extra-terrestrial impact. Data was collected through field observation, remote sensing, analysis of past geographical and geological studies, interviewing and laboratory analysis. Information has been presented in the form of analyzed satellite images, pictures, tables, and maps. Notably, this is the first study on extra-terrestrial impact cratering (ETIC) in Kenya. Consequently, the Silali basin, as an ETIC, and its environs, is a virgin field for further scientific research.

\section{APA CITATION}

Kipkiror, L. J., Rop, B. K., \& Ucakuwun, E. K. (2021). The Geology of Silali Basin (Kenya) as an Extra-Terrestrial Impact Crater (ETIC). East African Journal of Environment and Natural Resources, 3(1), 18-38. https://doi.org/10.37284/eajenr.3.1.278

\section{CHICAGO CITATION}

Kipkiror, Loice J., Bernard Kipsang Rop, and Elias Kerukaba Ucakuwun. 2021. "The Geology of Silali Basin (Kenya) as an Extra-Terrestrial Impact Crater (ETIC)”. East African Journal of Environment and Natural Resources 3 (1), 18-38. https://doi.org/10.37284/eajenr.3.1.278. 


\section{HARVARD CITATION}

Kipkiror, L. J., Rop, B. K. and Ucakuwun, E. K. (2021) "The Geology of Silali Basin (Kenya) as an Extra-Terrestrial Impact Crater (ETIC)", East African Journal of Environment and Natural Resources, 3(1), pp. 18-38doi: 10.37284/eajenr.3.1.278.

\section{IEEE CITATION}

L. J. Kipkiror, B. K. Rop, and E. K. Ucakuwun, "The Geology of Silali Basin (Kenya) as an Extra-Terrestrial Impact Crater (ETIC)”, EAJENR, vol. 3, no. 1, pp. 18-38, Feb. 2021.

\section{MLA CITATION}

Kipkiror, Loice J., Bernard Kipsang Rop, and Elias Kerukaba Ucakuwun. "The Geology of Silali Basin (Kenya) as an ExtraTerrestrial Impact Crater (ETIC)". East African Journal of Environment and Natural Resources, Vol. 3, no. 1, Feb. 2021, pp. 18-38, doi:10.37284/eajenr.3.1.278.

\section{INTRODUCTION}

For years, extra-terrestrial impact cratering was esoteric. However, extra-terrestrial impacts have become very important, largely, because they are associated with dinosaur extinction. Impact cratering by extra-terrestrial bodies including asteroids comets and meteors, is an important geologic process, not only for the minerals that it forms but also because of the knowledge that it poses an existential risk to life on earth. There is also the fact that extra-terrestrial impact crater building is a continuous process that may be going on even this very minute, somewhere in the universe and extra-terrestrial falling objects target the earth, just like other members of the solar system.

The mechanisms associated with impact cratering are diverse but generally, when a sizable solid body strikes the earth at high speed, shock waves propagate into the target rocks. At collision speeds of tens of kilometres per second, the initial pressure on the material engulfed by the expanding shockwaves is millions of times the earth's normal atmospheric pressure, which is 101,300 Newtons per square meter. This can squeeze dense rocks into $1 / 3$ of their normal volume. Stress can then overwhelm target rocks to an extent that they initially begin to flow almost like a fluid. A decompression wave follows the advancing front wave into the compressed rock, allowing the material to move sideways.

As more and more of the target rock becomes engulfed in the shock wave, which expands more or less radially from the point of impact, the flow of the target material behind the shock front, is diverted out along the wall of a rapidly expanding cavity created by the decompression wave. The compacted body now vaporized or melted moves outward with the divergent flow and lines the cavity, forming a conical sheet. Rocky material continues to flow outward until stresses in the shockwave drop below the strength of the target rocks. In large impact craters, the rock walls slump inwards, soon after excavation of the initial or transient cavity.

Whenever a falling heavenly body is not pulverized on impact, a meteorite will form. This is a heavenly rock sitting on an impact crater on the earth's surface. It may be an iron meteorite, iron-stony meteorite, or a stony meteorite. Stony meteorites are chiefly composed of silicate minerals, while iron meteorites comprise metallic iron and nickel. Stonyiron meteorites, on the other hand, contain large amounts of iron and rocky material. Stony meteorites can be chondrites or achondrites. Stony chondrites possess small rounded particles (chondrules) composed mostly of silicate minerals that appear to have been melted, while free-floating in space. Chondrites are typically old, for instance, about 4.55 billion years old and are considered the building blocks of the solar system (which is about 4.6 billion years ago). Achondrites are stony meteorites that are devoid of chondrules.

Extra-terrestrial impact Craters are divided into three categories according to their morphology, namely:
i) Simple Craters
ii) Complex Craters
iii) Basins

Simple craters are relatively small with a smooth bowl shape. In larger craters, though, gravity causes initially steep crater walls to collapse downward and 
inward, forming a complex structure with a central peak or peak ring and a shallower depth (Figure 1). The diameter at which craters become complex depends on the surface gravity and the planet. The greater the gravity, the smaller the diameter that will produce a complex crater. On the earth, the transition diameter of a complex crater is 2 to $4 \mathrm{~km}$, depending on the target rock properties [22]. On the moon, where gravity is low, the transition diameter is $15-50$ kilometres.

\section{Figure 1: Diagram showing a simple crater}

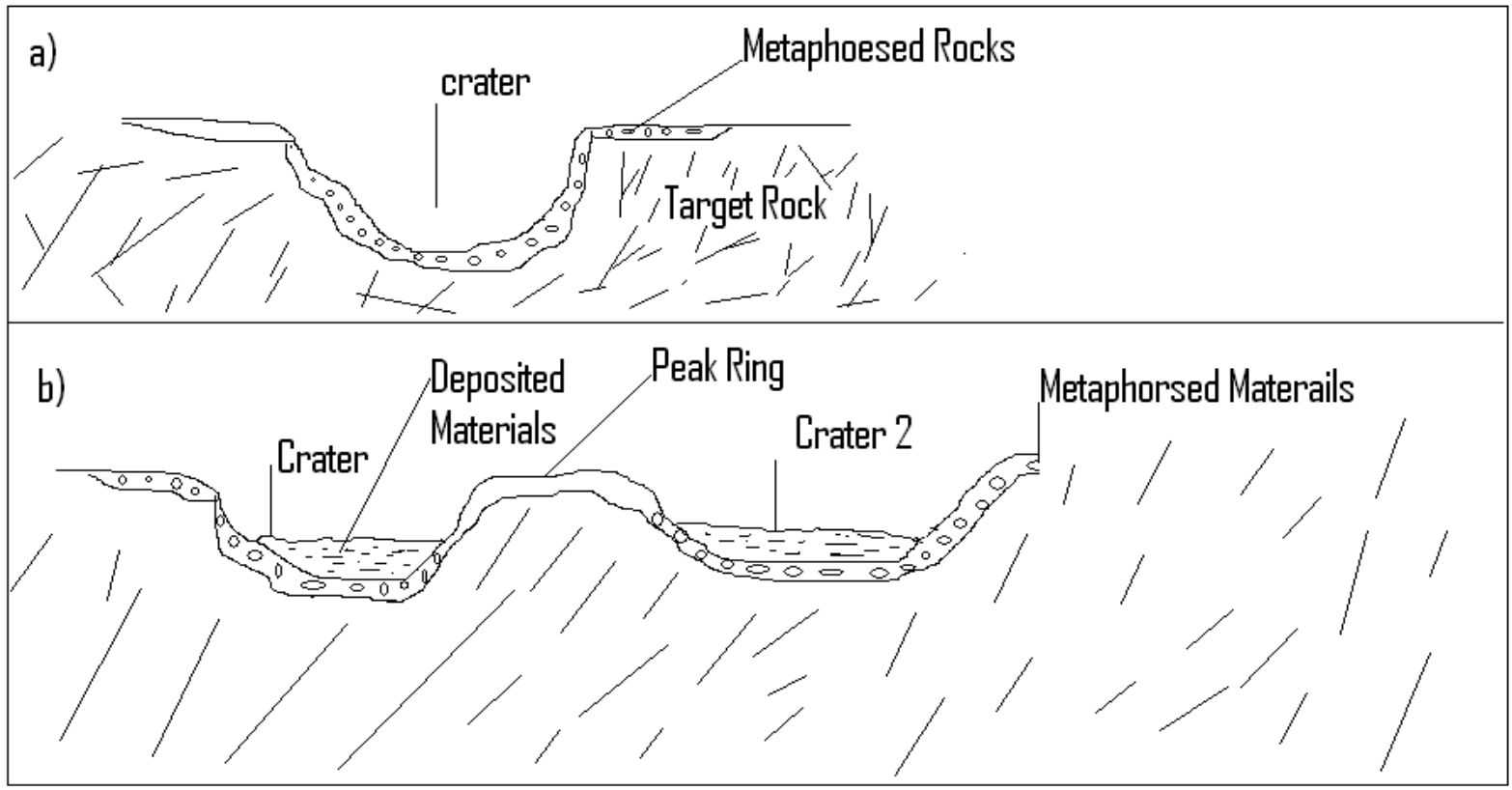

(a) and a complex crater (b) with associated features [7].

The peak ring or the central peak of a complex crater is formed when the initial (transient) deep crater floor rebounds from the compressional shock of impact. Slumping of the rim further modifies and enlarges the final crater. Complex structures on crystalline target rocks will also contain sheets of impact melt rock atop the shocked and fragmented rocks of the crater floor. On the earth's surface, tectonic processes, weathering, erosion, and human activities quickly deform an impact structure, though in some cases, the resistant rocks will stand out as concentric rings/peak rings within the crater. On the surface of the moon and other heavenly bodies, complex craters will be intact until they are destroyed by subsequent impact events [22].

A basin, on the other hand, is an ETIC whose diameter is large and with the increasing diameter, rings of peaks appear within it, transiting the complex crater into a basin. A single interior ring can qualify an ETIC into a basin [17]. It must be noted that ETICs can also form in marine environments and the morphology of a marine ETIC is quite distinct. Marine impact structures are characterized by a broad shallow brim, extensive sedimentary infilling, and prominent fault blocks on the floor [17].

\section{BACKGROUND OF THE STUDY AREA}

The principal criteria for determining whether a geological feature is an impact structure formed by the hypervelocity impact of a meteorite or comet are outlined below.

Presence of shatter cones that are on-site (macroscopic evidence).

Presence of multiple Planar deformation features $(P D F s)$ in minerals within the site lithologies (microscopic evidence).

Presence of high-pressure mineral polymorphs within in situ lithologies (microscopic evidence and requiring proof via $\mathrm{X}$-ray diffraction). 
The morphometry of the crater: -On other heavenly bodies such as the Moon and Mars, the shape of an impact crater is relied upon to determine its presence and type (simple or complex). This is a megascopic characteristic but requiring remote sensing and aerial photography for detailed mapping. On the earth, denudation and tectonic forces that resurface the craters, hamper the recognition of impact structures, solely by their morphology. The situation is worsened by certain terrestrial features being impeccably circular and appearing like impact craters. Volcanic craters (particularly Maars), salt diapirs, some glacial features, like cirques and kettle lakes and solution aided craters own the circular shape of an ETIC. This disqualifies the circular configuration, alone, as enough claim for a structure to be accorded the status of an impact crater. Buried craters that are revealed by geophysical techniques, also require a drill core to ascertain macro and microscopic evidence to prove an impact origin.

Presence of an impact melt sheet and breccias: These are macroscopic. Impact melt has a crustal composition derived from the fusion of target rocks and meteoritic/ impactor's components. The rock may also have some suevite (breccia composed of angular fragments of different rock types as well as glass inclusions) especially around the centre of the crater. Impact melt can be determined by sampling, followed by microscopic observation and geochemical analysis.

Pseudotachylites and breccias: - Pseudotachylite is a rock type generated by faulting at either microscopic or macroscopic scales. Unfortunately, pseudotachylites are also associated with tectonic faulting and are not, therefore, exclusively impact generated. However, the association of pseudotachylites with other impact features can make them one evidence of ETICs.

Presence of unshocked or preserved fragments of the impactor around or within a crater.

Silali crater has a near-circular shape, as shown by the satellite images presented, the DEM (Digital Elevation Model), the geological map, the ground photographs, and the aerial photograph. The basin also has shatter cones, PDFs, and breccia- among other impact-related geological features. Future studies in Silali should focus on unearthing Silali basin's High-Pressure Mineral Polymorphs, Impact Melt and Fragments of the basin's Impactor, besides profiling other ETIC characteristics of the basin [7].

Recently, on Saturday, $16^{\text {th }}$ of July 2011 , the people of Thika, Kangundo and Yatta witnessed an extraterrestrial impact event, when a meteorite fell on the area. A black stone from outer space, weighing 5 $\mathrm{kg}$ and $6 \mathrm{~cm}$ in diameter, was recovered from a farm. It is said that the stone fell on the farm at 1.017 hours and was accompanied by a thunderous sound and a tremor after it had impacted on the land. In addition, the object (now known as Kimwiri meteorite) blasted a small crater on the maize field, where it fell and displaced some dust that was visible from a distance. Plate 2 is a photograph showing the Kimwiri meteorite as it is today. This indicates that impact cratering is an ongoing process.

Plate 1: A natural colour SPOT satellite image showing the Silali crater, Marigat-Kapedo road (yellow), Suguta River (characterized by whitish sediments) and the outer basin around Silali.

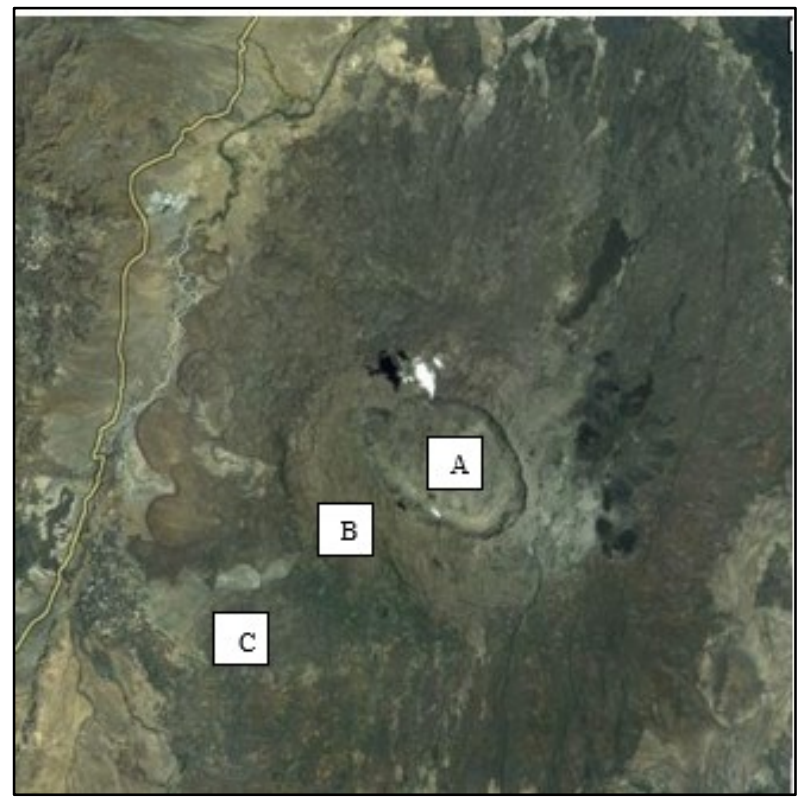

(A) is the Silali crater, (B) are the almost circular walls that surround the crater and $(C)$ is the outer basin surrounding the crater [7] 
East African Journal of Environment and Natural Resources, Volume 3, Issue 1, 2021

Article DOI: https://doi.org/10.37284/eajenr.3.1.278

Plate 2: Plate 2: A picture of the Kimwiri meteorite

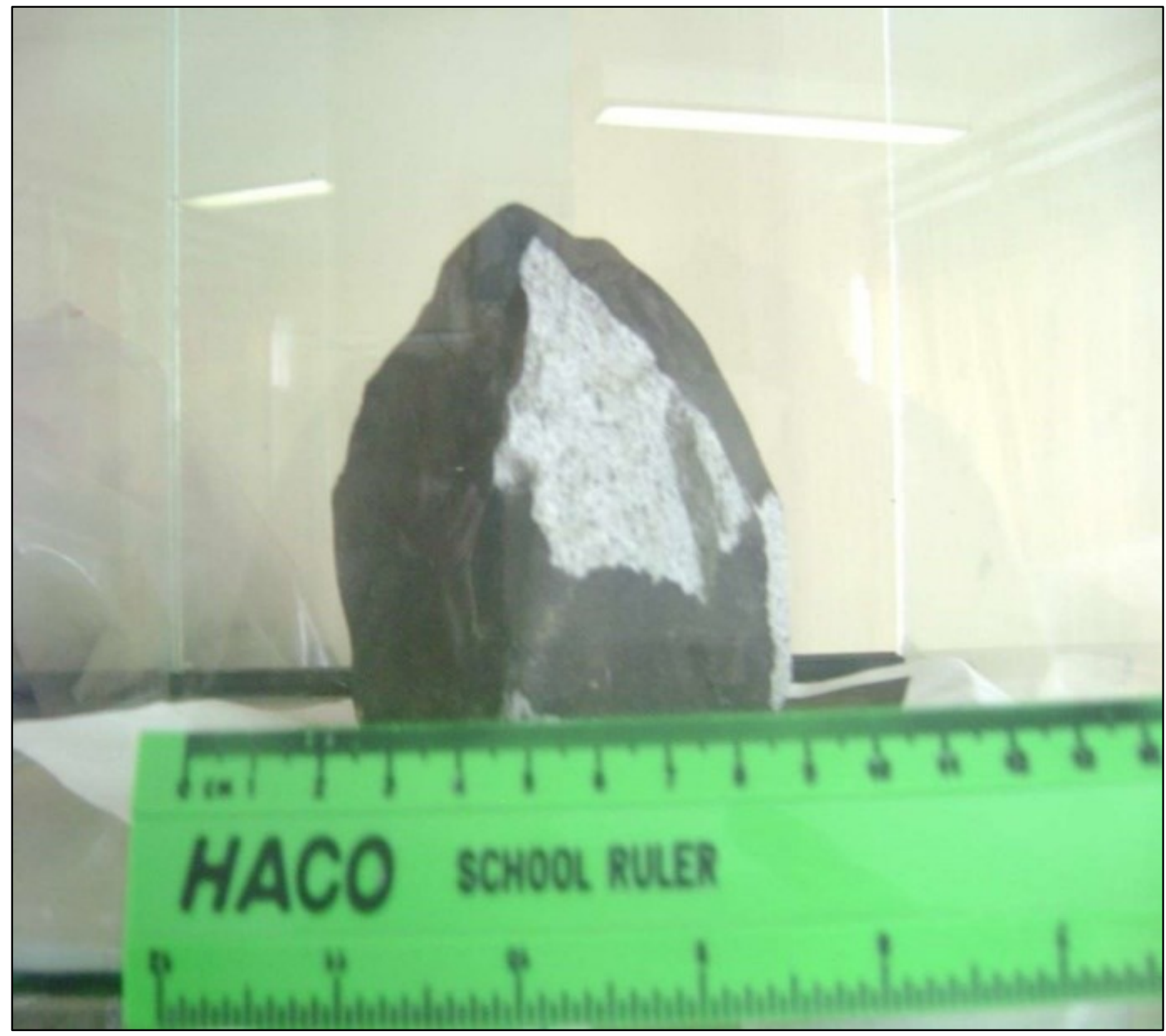

Taken where it sits at the commissioner's office, Department of Mines and Geology -Kenya [7] 
East African Journal of Environment and Natural Resources, Volume 3, Issue 1, 2021 Article DOI: https://doi.org/10.37284/eajenr.3.1.278

Figure 2: An aerial photograph showing a section of the western wall of the Silali basin

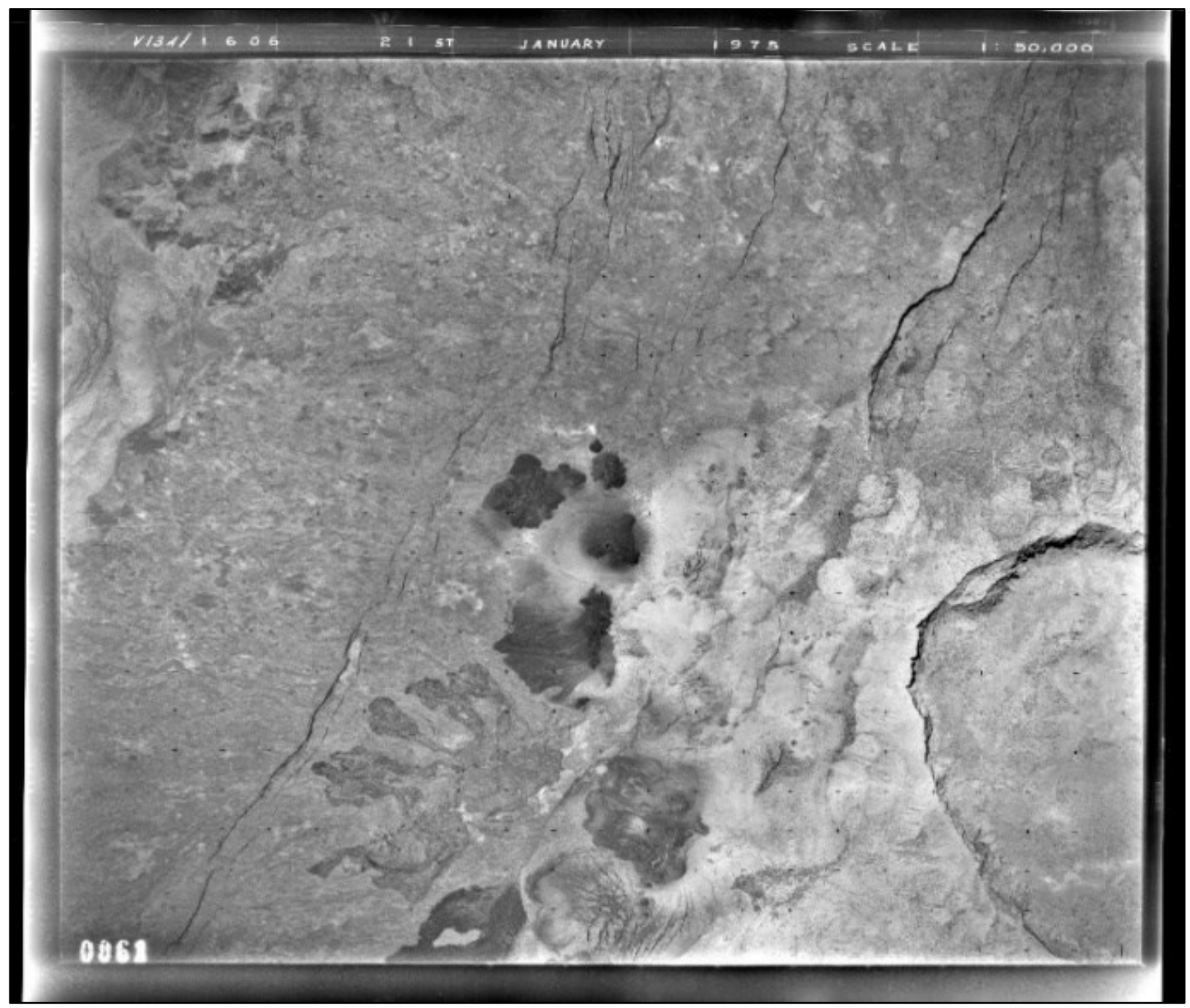

Source: (Survey of Kenya) [7]. 
East African Journal of Environment and Natural Resources, Volume 3, Issue 1, 2021

Article DOI: https://doi.org/10.37284/eajenr.3.1.278

Figure 3: A DEM (with elevations) showing Silali basin's (SB) hummocky terrain and morphology.

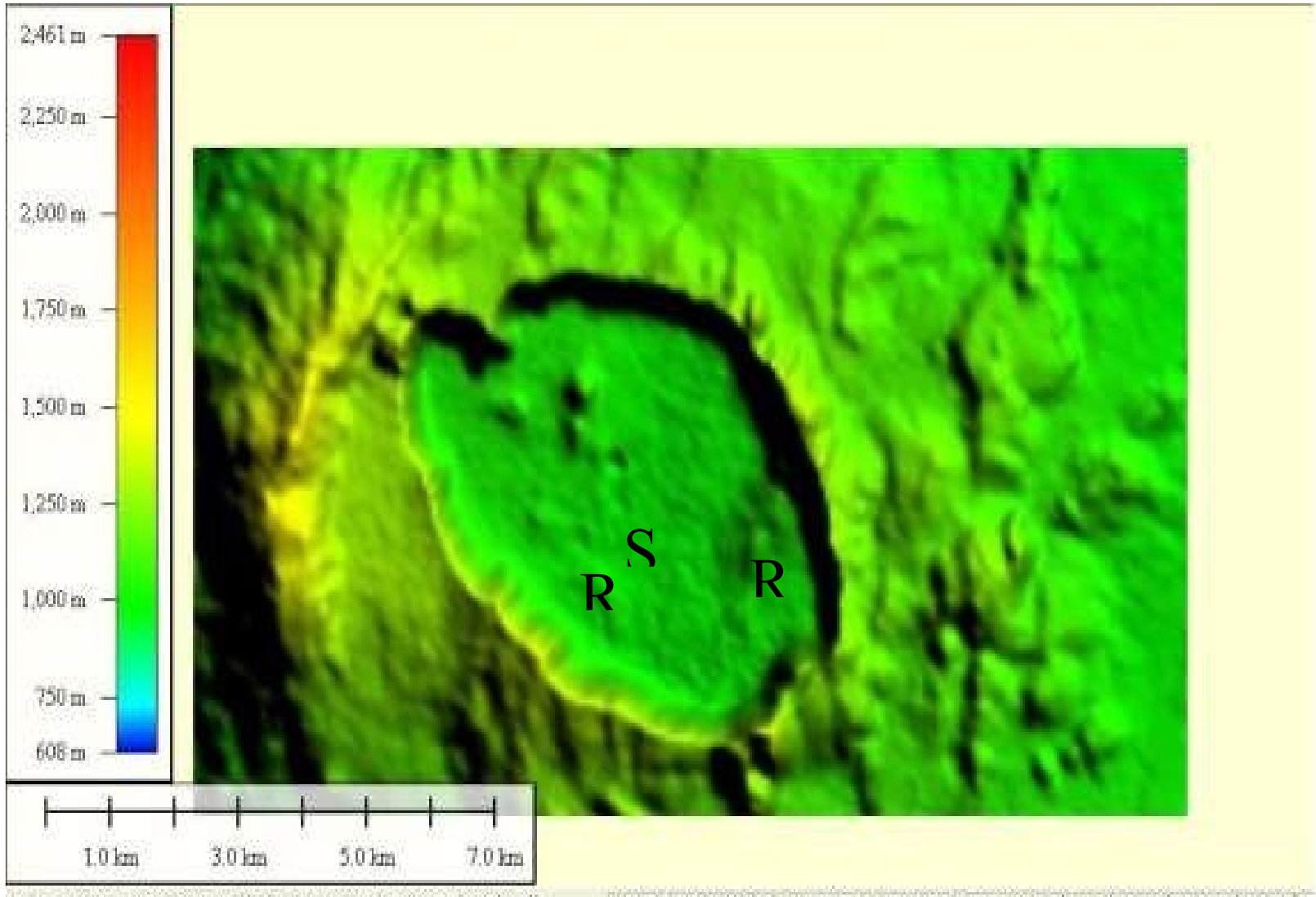

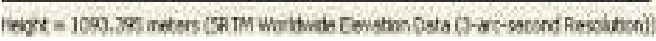

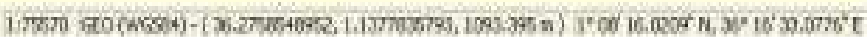

The DEM also shows the outline of Silali's probable peak ring (R) [7]. 
East African Journal of Environment and Natural Resources, Volume 3, Issue 1, 2021

Article DOI: https://doi.org/10.37284/eajenr.3.1.278

Figure 4: Simplified geological map of Silali basin

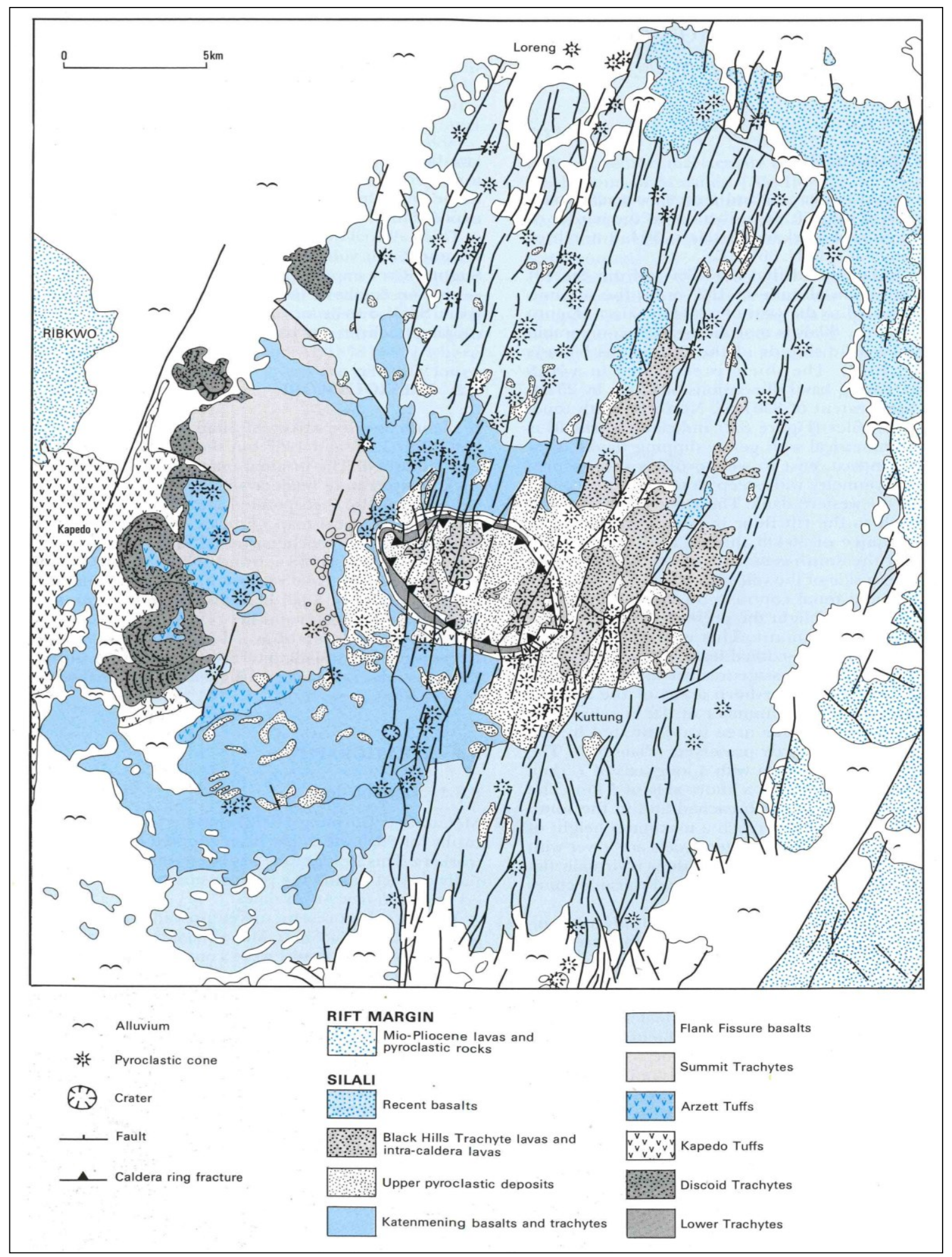

Shows the basin's ring-like structure, the fault lines cutting across the basin and Silali's multiple cratering [7]. The dust blanket over the Silali basin's wall is also visible on the map. Noting that the material making up the basin's wall is not uniform [7]. 
Plate 3: A picture showing Silali basin's circular shape and hummocky floor

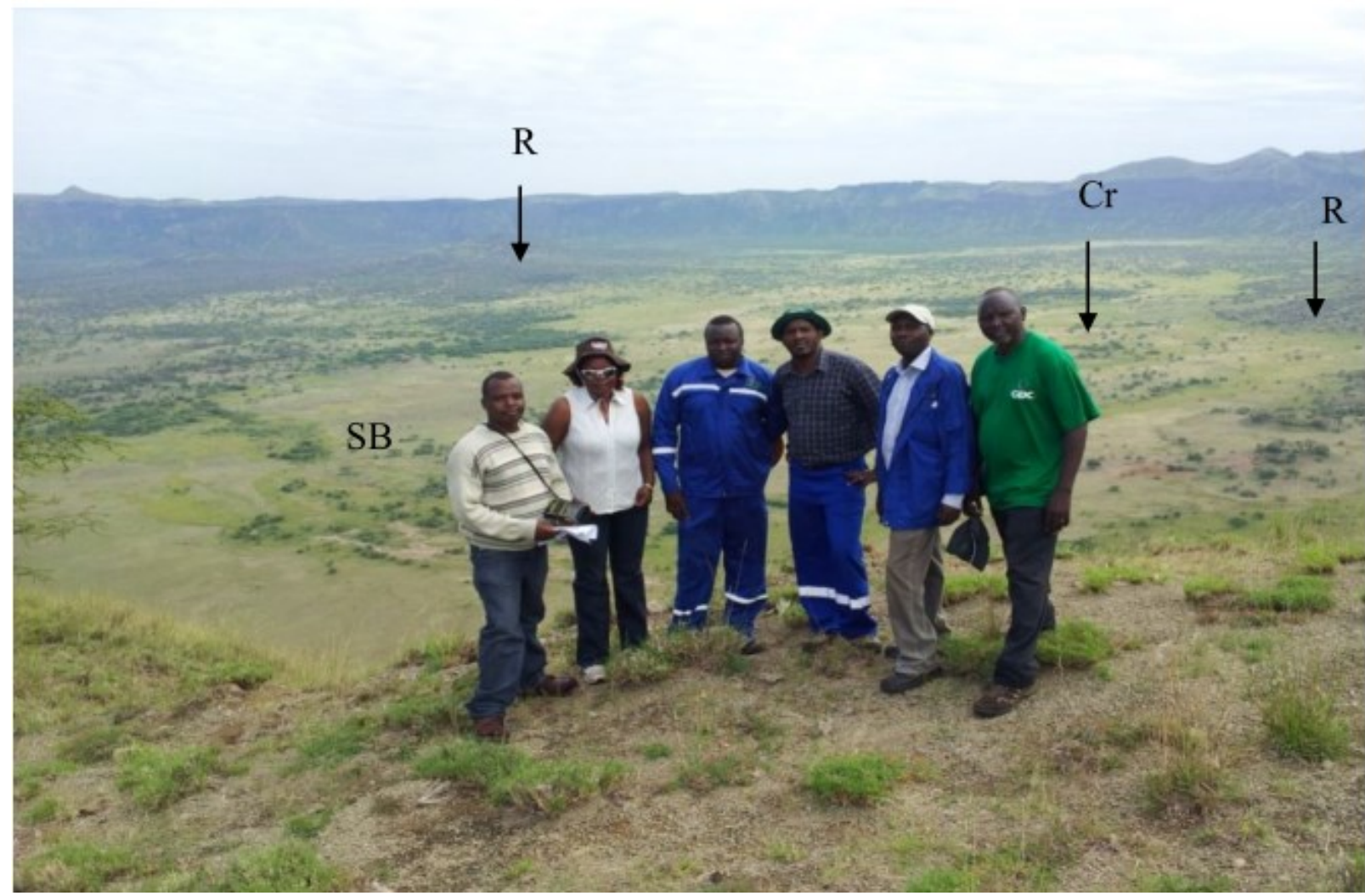

Craters (Cr) and ridges (R) as viewed from the Southeastern rim of the Silali Crater (SB) [7].

Another recent impact event on Kenyan soil is the Kuresoi-Nakuru County, fireball event that took place around 7:30 pm local time, on Thursday, $27^{\text {th }}$ February 2014. This entailed a space object that cruised through the Kenyan space, sighted by many and landed on Kipara village-Kuresoi (approximately, 0³'S, 355'E) burning down a mudwalled-grass-thatched house and injuring a woman [7].

\section{LOCATION OF THE STUDY AREA}

The study reported in this paper covers the Silali basin, also known as Silale and its environs. Silali basin is found in East Pokot/Turkana East, within the mid Graben of the Great Rift Valley, $50 \mathrm{~km}$ north of Lake Baringo and near Kapedo Town. It is located on Latitude $1^{0} 10^{\prime} \mathrm{N}$ and Longitude $36^{0} 12^{\text {' }}$ E. Turkana people call it Silali while the Pokot call it Silale. The basin covers an area of about $850 \mathrm{~km}^{2}$ and has a NNE diameter of about $5 \mathrm{~km}$ and an ESE diameter of $8 \mathrm{~km}$. It can be estimated that the impactor's size, could be $0.25-0.4 \mathrm{~km}$ in diameter or $42.5 \mathrm{~km}^{2}$ in area, based on the rule that an impactor's size is $1 / 20$ the crater's size [1]. Consequently, the Silali impact event may have been a huge event [7].

Figure 5 is a map of Kenya showing the location of Silali basin. Geographically, the area is in southern Turkana but administratively, it is at the border of Turkana East and East Pokot districts. It is an area whose ownership is disputed between the Pokot and the Turkana communities, hence frequent fights over pasture. In addition, the Silali area is very rich culturally, being endowed with special archaeological sites [7]. 
Figure 5: A map of Kenya, drawn to scale, showing the study area, pointed by a blue arrow and circled in red [7].

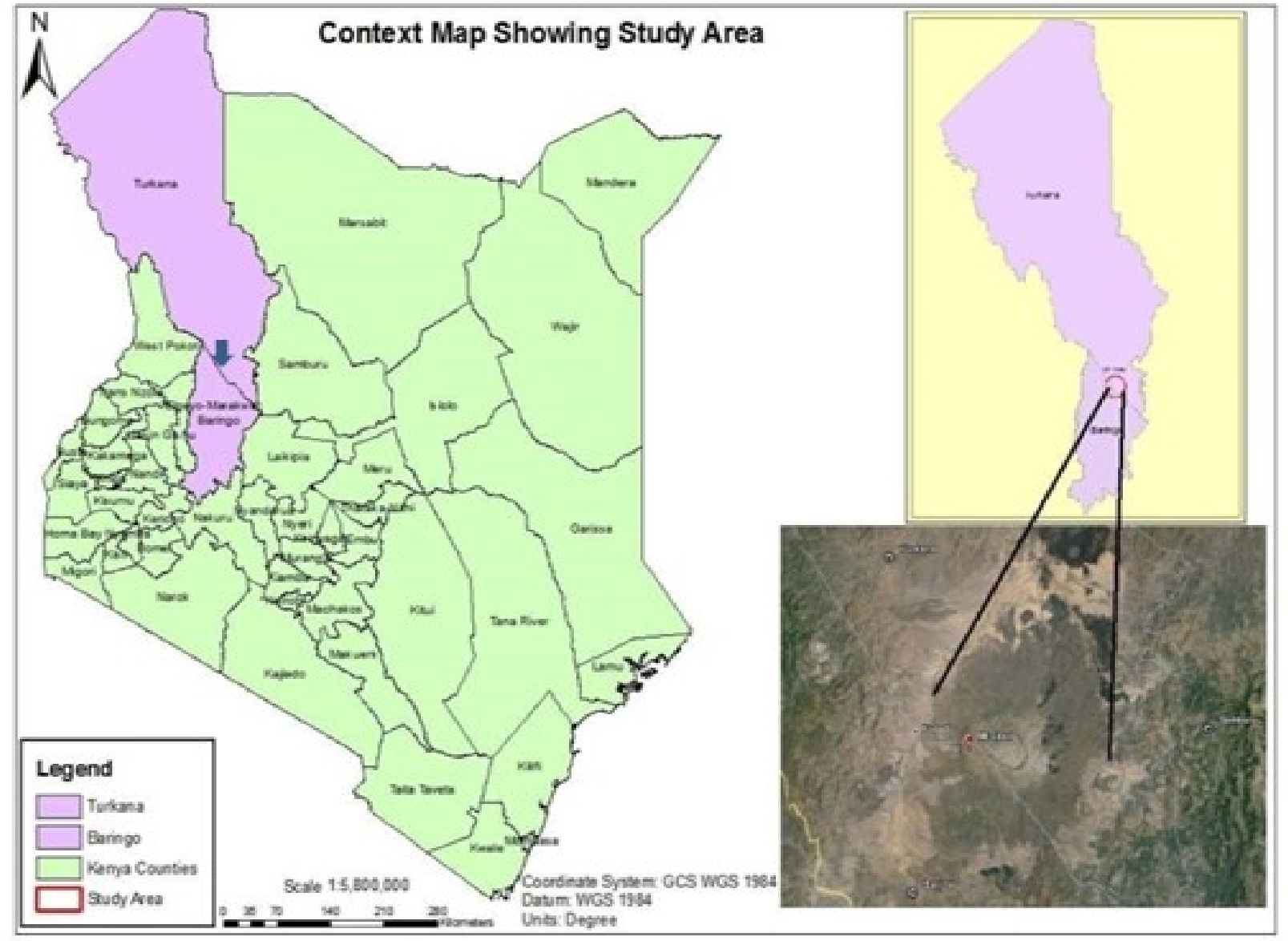

From Figure 5, the Silali basin, circled in red, is to the south of L. Turkana, to the northeast of Eldoret Town, to the north of Nakuru Town and $50 \mathrm{~km}$ north of L. Baringo, near the small semi-rural town of Kapedo. It is in a very remote area that can only be adequately accessed by heavy four-wheel vehicles or a helicopter [7].

\section{THEORETICAL FRAMEWORK}

Silali basin is an environmental resource whose existence is of enormous socio-economic value. Unfortunately, the basin's importance, as an ETIC and an environmental resource, has not been fully realized. 'The Tragedy of the Anti-commons' theory can aptly explain this scenario [7].

The term 'Tragedy of the Anti-commons' was originally coined in a 1998 Harvard Law review article by Michael Heller. In a 1998 article in
'Science', Heller, alongside Rebecca Eisenberg, pointed to biomedicine as one of the key areas where competing patent rights could prevent useful and affordable products from reaching the marketplace. This is because, too many property rights can lead to too little innovation [5], $1^{\text {st }}$ May 1998).

The freely existing resources in Kenya include in this case, the unknown ETICs, appending Silali basin, and their immense geomorphic wealth. These common resources are untapped for their economic worth. Kenyans may be acting individually in their 'non-utilization' of these resources but overall, the loss that accrues from their not using the resources is borne by all. For example, national poverty may partially proliferate due to a lack of interest in untapped tourist and mineral resources, citing ETICs. Some countries have discovered the tourism potential of ETICs. In the USA, a meteor crater 
located $69 \mathrm{~km}$ East of Flagstaff, near Winslow in the northern Arizona desert (the Barringer crater) is a popular tourist attraction in the region. There is a $\$ 15$ entrance fee to see the crater, for adults [17]. The crater is owned privately by the Barringer family [17].

\section{MATERIALS AND METHODS}

The researcher employed a Mixed Methods Design of research where qualitative (observation and interviews) together with quantitative (remote sensing, sampling, and laboratory testing) research approaches were used to collect data. Data collection materials included a camera (working with a checklist), polythene bags, a small hammer, pens, labelling papers, tapes, a ruler, and a notebook. Data collection tools entailed a checklist, laboratory testing, visual interpretation of satellite images, analysis of photographs and pictures, analysis of geophysical data and terrain analysis, using a GIS software (Global Mapper) [7].

Remote sensing (Satellite Imagery, Aerial Photography and Ground Photography) was variously used to:

i) Reveal details about the Silali basin, for instance, its size, shape, and associated features.

ii) Identify the general topography of the area where Silali crater is found and the alignment of rock formations in the area and

iii) Provide images and pictures of the basin, its related features, and the surroundings.

Satellite images were important and useful in this study because of their clarity in the appearance of the features on the earth's surface. Hand camera ground pictures of features around and within the Silali basin were also acquired. First, these were a means of data collection but were used to record and store whatever information was collected [7].

An aerial photograph was used to confirm features found in some of the satellite images. It provided an important means of data comparison [7].

Qualitative research interview was used to obtain the understanding of the people, living in the proximity, about Silali basin's existence and any folklore that has been passed on through generations regarding its formation. Exploratory interviews were also tactfully conducted, during the study, to seek the local people's understanding of the basin's importance. The interviewees were sampled through a 'by chance' kind of sampling; wherever and whenever they were found, which was by chance because of the insecurity that prevails in the area [7].

The researcher visited the Silali area, to observe the nature of the basin, its environs, and associated features [7]. The observation that was done in this study was mostly non-participatory. It involved taking into consideration the observations made by field guides on the observable features of the basin. In addition, rock and soil samples were collected for chemical analysis. Pictures of the rock samples, rock formations in the study area and associated features were taken [7].

Probability sampling was done to give each area of the field a chance (greater than zero) to be sampled or to be selected as a site for collecting a sample. Noting that probability sampling can apply systematic and stratified sampling, simple random sampling (SRS) was used for the collection of all samples and in the 'by chance' sampling of interviewees [7].

Laboratory testing was essentially carried out to establish the chemical composition of rock samples collected from within and around the basin, with the aim of finding out whether the rocks from the area of study bore mineral elements and mineral formations that are associated with ETICs. The mineral elements of interest included Silicon Oxide $\left(\mathrm{SiO}_{2}\right)$, Aluminum Oxide $\left(\mathrm{Al}_{2} \mathrm{O}_{3}\right)$, Sulphur Oxide $\left(\mathrm{SO}_{3}\right)$ and Iron Oxide $\left(\mathrm{Fe}_{2} \mathrm{O}_{3}\right)$ - among others (Figure 7). The mineral formations that were of interest encompass high-pressure mineral polymorphs, Planar Deformation Features (PDFs), silica and siderophile elements [7]. All the laboratory tests were carried out by technicians at the Department of Mines and Geology-Kenya.

Laboratory tests were not carried out to determine the Silali basin's age because this had previously been reported to be about 62-64KA [2, 11]. The ages of most of the ETICs on the earth's surface are known thus, it is necessary to also document the age of the Silali basin because there is a coincidence 
between the ages of Hypervelocity Impacts (HVIs) crater formation and major events on the earth's surface. Impact cratering is closely associated with instantaneous drastic environmental change [7].

Identification of the chemical components of the rocks around or within the basin provided useful information on the mineral potential of the basin, for economic purposes. Geophysical data was used to determine the Gravity, Magnetic, Seismic and Electric signatures of the Silali basin. By its nature, geophysical data is very expensive to acquire. Consequently, secondary data sources were relied on and the Silali basin's geophysical characteristics were deduced from a geophysical study of the area [10]. Terrain analysis of the area of study was done through the drawing of topographic sections of the area and the drawing of a Digital Elevation Model (DEM) [3].

\section{RESULTS AND DISCUSSIONS}

\section{Formation of Silali Basin}

Silali volcano was formed around 225KA and the caldera (crater or basin) collapsed around 66-62KA [22]. Previous studies by some scholars who carried out research in the Silali basin indicated that there existed a volcanic shield where the Silali basin is. The shield seems to have been stretching in a northsouth direction. Silali's volcano started forming 400-220KA. This included the formation of a low relief lava shield [7]. Volcanic eruptions in Silali occurred during different times and some of the later ones, according to the authors, resulted in an inward collapse of the shield summit, owing to the lateral drainage of magma from beneath the volcanic shield. According to the scholars, these are the eruptions that led to the formation of the caldera around 66-62KA [2, 11]. The existence of a volcanic shield in Silali before the ETIC formed is favoured by the following incidences:

i. The fact that Silali basin's wall is made up of volcanic materials placed in layers.

ii. The non-contemporaneous nature of the wall materials in terms of age and physical characteristics; and

iii. The 'break off' or stepped walls of the Silali basin, which may be layers of different volcanic materials, bearing different strengths against denudation.

Other scholars, however, came up with a proposition that there existed an earlier caldera before the present 'volcanic caldera' with the 'break off walls' (stepped walls) of Silali basin, mark the traces of an earlier caldera [2, 16]. Not all scholars agree with this theory. Others opined that these features are indicative of a bonding within an early caldera, but then some mechanism of topographic inversion is required [18]. This mechanism of topographic inversion can be provided for by an extra-terrestrial impact.

As a volcanic shield, caldera formation by subsidence involving a volcanic pipe is not plausible for the Silali basin. This is because subsidence would not be a quiet event and an explosion would most likely occur, pouring out magma onto Silali walls. One would then expect Silali to exhibit magma outpourings from its ring structure onto its flanks. This is not the case. Again, the collapse would not produce a perfect ring structure unless there was an outline of a ring structure in existence [7].

Caldera subsidence occurs in various ways, such as through plate/piston subsidence, trap door subsidence, chaotic subsidence and downsag subsidence, among others. Plate or piston subsidence involves the subsidence of a coherent block of rock into a magma chamber that evacuates magma along a ring fault. The caldera floor may be variably faulted, but the faults are less active than the ring faults [22]. Trap door subsidence, on the other hand, is subsidence that involves multiple collapse centres. It is a piecemeal subsidence. As for chaotic subsidence, wholesale disruption and brecciation of caldera floor rocks are involved. This generates low-density materials which cause a caldera to register a low gravity signature. Finally, downsag subsidence occurs when ring faults either do not form or do not penetrate the ground surface so that summit material subsides by bending downwards.

Silali's subsidence may be said to be a plate or piston type of subsidence because the rock layers forming the basin's walls show continuous uniformity in material type and height. This is supported by observations made by Dunkley and 
team [2], that; the caldera has a regular outline and vertical walls suggesting that it was formed by a piston-like collapse.

Silali's subsidence can be said to be the factor behind the basin's stepped or 'break off' walls, because as subsidence occurred, the more resistant rocks of the basin's wall remained standing while the softer parts collapsed more and later got washed away by denudation. Denudation removed the softer rocks that made up the initial walls of the volcanic shield, forming scalloped areas, while resistant rocks, such as the young volcanic rocks making up the topmost layer of Silali basin's wall, remained intact, forming the wall's protruding parts. There is a lot of evidence along the basin's wall, supporting subsidence and especially block/piston/plate subsidence [7]. These include:

- The layers that make up the Silali basin's wall are almost uniform and continuous around the basin and at the same height as the basin's floor (about $300 \mathrm{~m}$ for the top-most layer).

- The walls appear to have collapsed inwards, towards the basin. There is an appearance of 'turning inwards' on the Silali basin's inner walls, which is different from the 'turning outwards' appearance of the basin's outer walls. Slumping has modified the appearance of the basin's inner walls, giving the walls a concave appearance.

Subsidence was possible for the Silali basin because, after a probable extra-terrestrial impact, fractures formed around the basin, encouraged by pre-existing rock weaknesses, some of which built the Silali volcanic shield (400-200KA). The impact must have also widened the existing rock cracks, triggering the exit of magma from within the shield's magma chamber onto the areas around the basin. This should have formed some amount of emptiness beneath the impact basin, bringing about a collapse that left high stepped walls. There is evidence (in the form of brecciated and metamorphosed rocks on the crater walls) that hot gases and liquids hissed out of the crater chamber through the many fractures surrounding the crater.

From the pictures and satellite images of the basin, one can clearly see volcanic cones around the basin. These were built by magma that outpoured from the impact area, forming part of the evidence of subsidence in Silali. The volcanic cones sitting on the basin's walls would be as old as the Silali volcanic shield, being the products of the shield's parasitic fissures [7].

The following simplified schematic diagrams can explain the formation of Silali basin, especially the volcanic shield and impact stages [7].

\section{Figure 6: Schematic diagrams showing the formation of the Silali basin.}

(i)

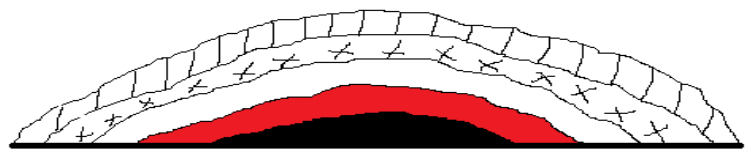

(ii)

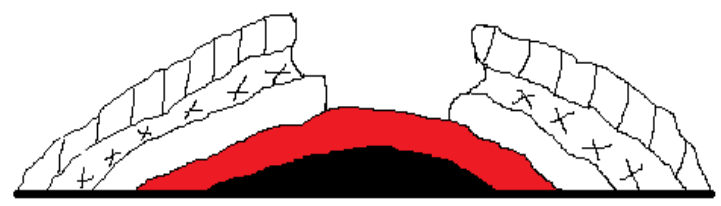

(i) Represents the pre-impact volcanic shield. The shield is made up of different layers of volcanic rock. (ii) Represents the post-impact volcanic shield [7].

\section{Geology of the Silali Basin}

The ETIC related geology of the Silali basin comprises:

\section{Allochthonous}

Allochthonous such as rock fragments around the rim are present in the Silali basin. This is the material that appears to have been displaced during cratering. The fractured rock, on the outside walls of the basin, is very similar in appearance to the rocks found on the interior walls. This means that the rocks and the rough dust (a mixture of small rock particles and fine dust) found on the outside walls of the Silali basin, maybe part of the pulverized rock that was pushed out of the basin after impact. 


\section{Impact Ejecta}

The whole of the Silali volcano has an enveloping of an alluvial apron (sediments) [11]. Thus, the presence of massive rough dust deposition (or 'apron of alluvium') on the flanks of Silali basin, instead of magma deposition, is evidence that Silali basin may be a product of an extra-terrestrial impact rather than volcanicity [7]. This rough dust is not volcanic tuff because it is not uniform in colour or in physical composition. It is more like a juxtaposition of pulverized rock materials and dust that has been cemented together. It is important to note that the basin is rich in volcanic rocks and the broken-up rock materials mentioned here, may have been cemented together by Silicate minerals that are present in the rocks or by impact melt if indeed Silali is an ETIC.

The possibility of an impact event behind the basin's formation can be inferred from the presence of broken up obsidian in the impact dust around the basin. As stated above, dense obsidian layers are found in the materials making up the Silali basin's western walls. The rock also appears as thin lines within the layers of the basin's wall in other places. It is only an impact event that can crush or pulverize the walls of the old Silali volcanic shield, excavate a crater and push rock fragments and dust over the crater walls [7].

It should be acknowledged that the Silali basin's walls have no lava deposition. Secondly, the crater is not a product of a vent eruption and thirdly, the ring structure is not eruptive in terms of magma emission, as discussed herein. Consequently, the material making up the dust apron around the basin, though volcanic to a large extent, is not a product of magma deposition or volcanic tuff. The material is a mix of whatever rock materials made up the volcanic shield from which the Silali basin was formed, obsidian included [7].

Plate 4 shows the rough dust that covers the flanks of the Silali basin, on a larger scale. Plate 5 shows the same dust at close range and Plate 6 shows obsidian particles that were collected from the dust [7].

\section{Plate 4: The dust (D) on the flanks of Silali basin, on the southeast and eastern walls [7]}

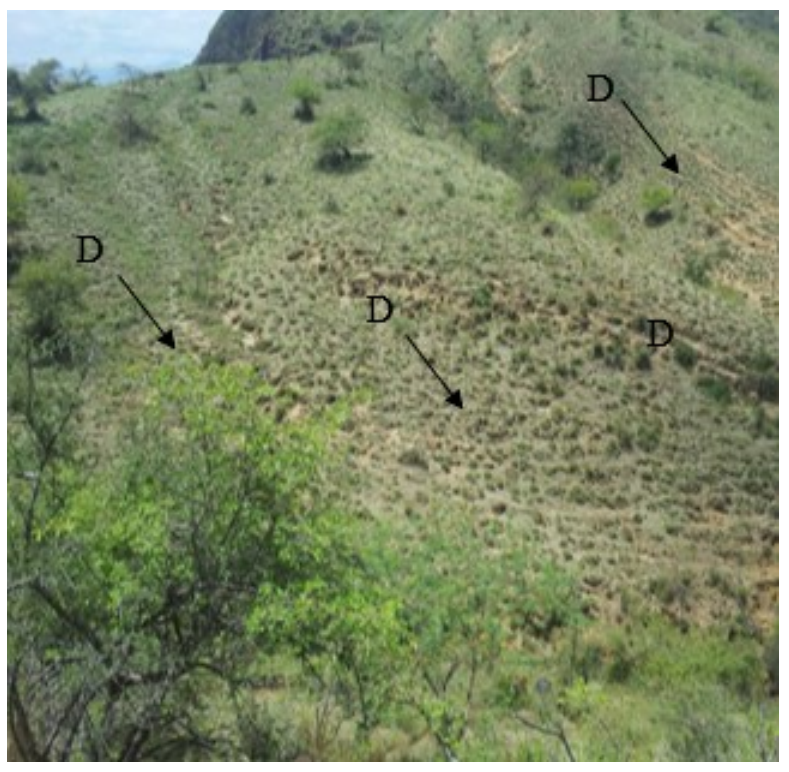

Plate 5: The dust (D) at close range [7]

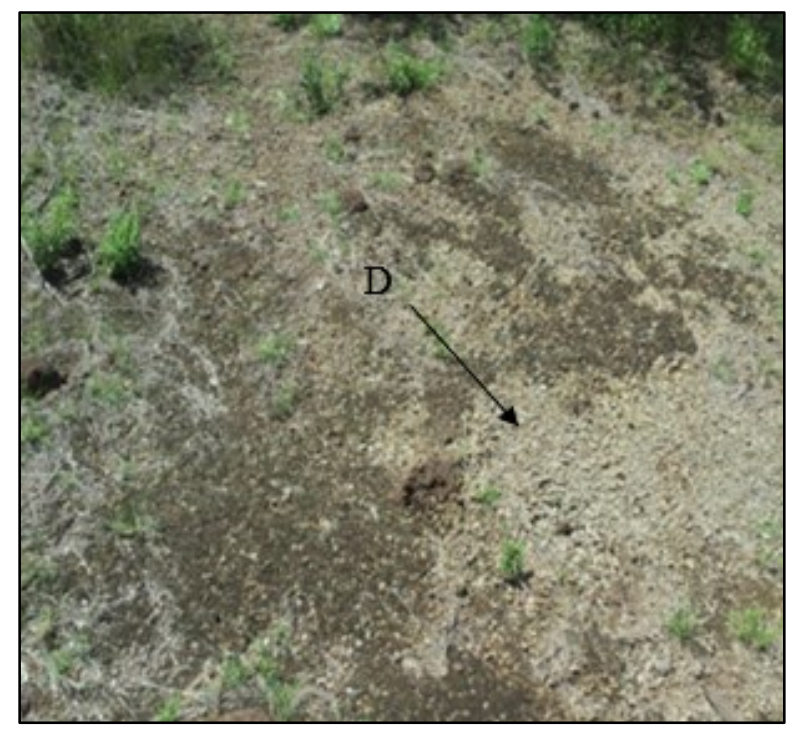


Plate 6: Broken obsidian particles found in the dust around Silali basin [7]

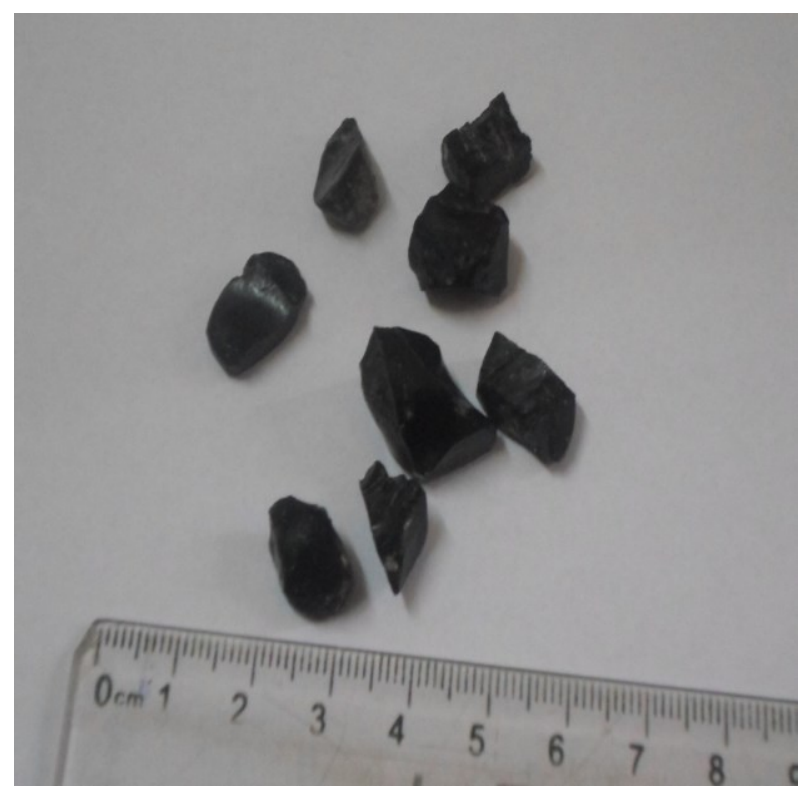

The obsidian particles were picked from a handful scoop of the dust that is called ejecta in this study. The dust is rich in many rock particles, but obsidian was picked to show that the rocks inside the Silali basin may have produced the dust around the basin [7].

As stated earlier, there is the absence of massive lava deposition on the flanks of the Silali basin. If the Silali basin was entirely a product of volcanic activity, there would be the presence of this lava within and all around the basin's walls.

\section{Breccias}

Breccia is found in the crater. The lower layers of the north-eastern wall of the caldera, for instance, consist of massive trachyte lithic breccias while the northern wall has up to $10 \mathrm{~m}$ of polymict lava lithic rich breccias [2]. Lithic and Polymict breccias are breccias whose particles are cemented in a way that they form a matrix. In fact, lithic breccia is an impact breccia that contains shocked and unshocked clastic material in a clastic matrix [7].

Breccias have varied origins. They may be sedimentary, tectonic, igneous, and hydrothermal and impact related. Sedimentary breccias are deposited in valleys (clastic rock) while tectonic breccias are formed on the margins of tectonic boundaries, following a collision, or shearing of continental plates. Igneous breccias are volcanic bombs that have been cemented together while hydrothermal breccias are formed in areas where there are geysers. When the walls of voids containing hot water collapse, rocks implode inwards and are caught up in a churning mixture of rock, steam, and boiling water. The rock fragments deminutate each other and become rounded, forming breccias with rounded particles rather than angular particles as those shown on Plate 7. Silali basin's fracturing and release of hot fluids may have also contributed to the formation of the breccias, on the surface rocks in and around the basin. Breccias formed by hydrofracturing have angular particles, just like impact breccias and if boiling occurs, methane and hydrogen sulfide may escape, encouraging the precipitation of mesothermal ore deposits, which often contain gold [7].

Impact breccias are found on the rim or floor of an ETIC. They may also be found on the ejecta expelled beyond the crater and are identifiable by their occurrence in or around an ETIC, in association with other impact features. There is no clear explanation on how they formed but it may be because of impact heat fusing all sorts of rocks together [7].

Silali basin's breccias may still be impact related, whether they were formed directly by impact or by a hydrothermal fracturing activity. This is because, for the hydrothermal fracturing to occur and form mesothermal breccias, there should have been some weakness in the area rock that encouraged the superheated fluids from deep within the basin to charge upwards under lithostatic pressure. Silali basin's fracturing, is impact related, especially the ring fracturing; that may be responsible for the basin's ring fracture structure [7].

Suevite was not found in the crater and it should be the investigation of future studies. Plate 7 shows brecciated rock on a section of Silali basin's walls. 
Plate 7: A picture showing brecciated rock on Silali basin's south-western wall [7]

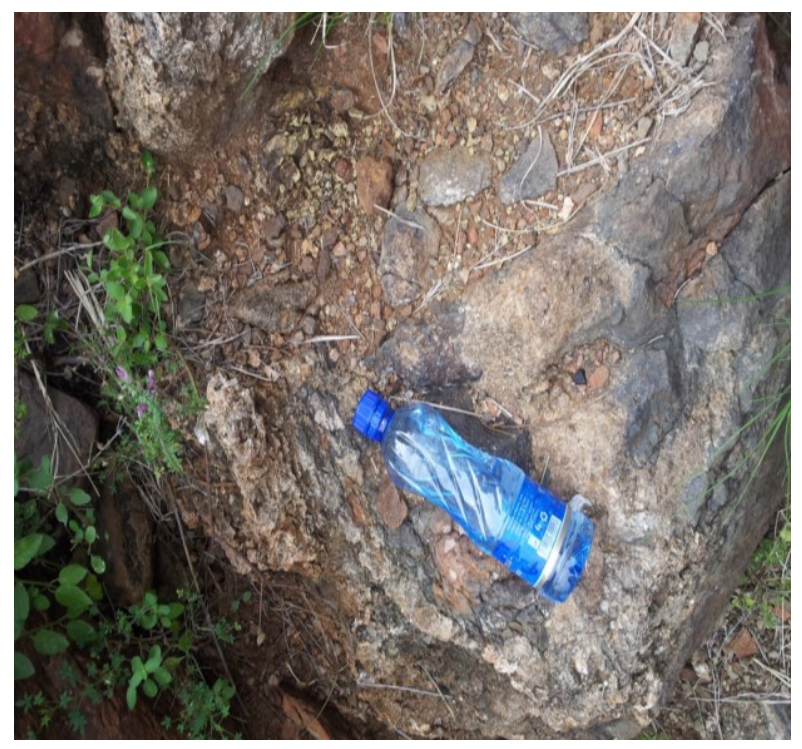

\section{Silali's Shatter Cones}

The upper layer of rock making up the inner walls of the Silali basin appears like a mass of shatter cones. The broken pieces display conical fracture surfaces, just like the Chemolingot shatter cones and other shatter cones. Shatter cones form mostly on fine-grained brittle rocks, just like the rock layer in question. Plate 8 shows the Silali basin's shatter cones [7].

\section{Plate 8: A picture showing Silali basin's shatter cones [7]}

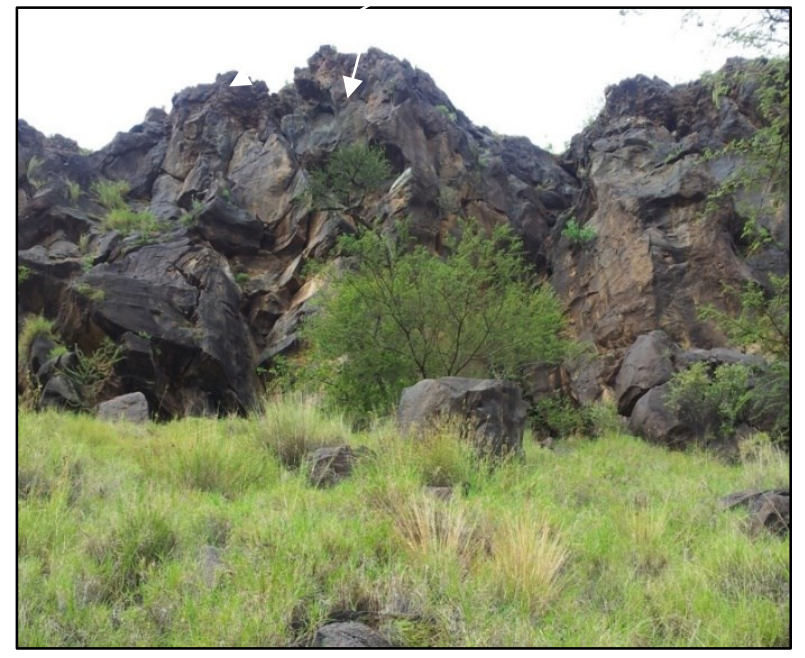

The rock (dark) shown on Plate 8 is of volcanic origin and is more exposed on the inside of the basin. On the outside of the basin, it is buried by the rough dust that envelopes the Silali basin. Some of it, however, are the huge blocks that make up the basin's hummocky ejecta and a large part of the pseudotachylites littering the basin's floor and outer walls [7]. It is made up of striated fracture surfaces and is continuous all around the basin, at an almost uniform height. The rock is rapidly breaking up and this has made it more rugged as parts of it are chipped off.

Interestingly, the shatter cones on the Silali basin and Chemolingot shatter cones have their conical tips facing the East [7]. Shatter cones are rare geological features that are only known to form in the bedrock beneath meteorite impact craters or in areas where underground nuclear explosions have occurred. Geologists believe that shatter cones form due to compression waves passing through rocks after an impact or because of tension/refraction as rocks bounce back when pressure subsides. Shatter cones range in size from microscopic to several meters large, depending on the rock type. Coarsegrained rocks tend to yield less developed shatter cones but fracture more during impact. Shatter cones develop more on dense- compact - finegrained rocks that get subjected to a high-velocity impact (HVI) [7].

\section{Tektites}

These are also found around the Silali basin. They are natural silica-rich homogenous glasses formed by the complete melting of target rocks. It is believed that the black hills to the East of the Silali basin are made up of pure black glass. However, 'the trachyte cones (Black Hills) to the east of the basin's wall are made of almost pure black glasses' [2] [11]. Though access to the black hills was not possible due to insecurity, owing to marauding cattle rustlers, the description of the trachyte cones suggest an impact origin; first because the glasses mentioned are black to blackish-brown in colour, just like tektites in other ETICs. Secondly, some of the glasses have a needle-like shape, such as the apatite glass [7]. Tektites are usually spherical in shape and therefore needle-like at some point.

Siderophile elements like iridium, osmium, platinum, and palladium which are also associated with ETICs were not observed in the Silali basin [7]. More research will have to be carried out in the 
Silali basin to ascertain the existence of the Palladium Group of Minerals (PGMs) or establish their nonexistence. According to the Journal of Geological Society of 1995, the basalts of the Silali basin are of high iron affinity (Journal of Geological Society, 1995). This may be the result of the existence of PGMs.

\section{Pseudotachylites}

These are also found within and around the basin. They are heavily faulted or fractured rocks. Though they can be formed by tectonic fracturing, they can also be formed by impact cratering. Generally, the area around the basin is heavily faulted but the faults are in a linear form and not likely to have formed Silali basin's ring fracture.

Silali basin's ring fracture, the caves, the sinkhole and the Suguta gorge, among other features in the area, all provide evidence of the massive rock faulting or fracturing within and around the basin [7].

\section{Other Related Minerals}

A study that was carried out by the Department of Mines and Geology, following a governmentfunded project on mineral exploration and assessment of geological materials and geotourism sites in ALRMP project area of Baringo and East Pokot districts in 2009, revealed that the Silali area also has other minerals that are impact related. These include iron, gold, copper, and nickel [3].

Many large ETICs host mineral resources that range from large deposits to localized occurrences. ETIC minerals can be progenetic, syngenetic, or epigenetic. Progenetic minerals are pre-impact minerals. These are minerals that existed in target rocks before an impact event but may have become exposed or accessible after impact. They include iron ores, uranium, and gold. Syngenetic minerals, on the other hand, are syn-impact minerals or minerals that owe their existence purely to an impact event. They include copper, nickel, PGMs and impact diamonds. Epigenetic minerals, as far as impact is concerned, are post-impact minerals. These are minerals that result from impact-induced thermal activity.

Apart from a few metalliferous deposits and mesothermal gold, impact hydrocarbons form the bulk of many epigenetic impact deposits. This is because; impacts do not only encourage the burial of plants and animals under pressure and heat, to degrade them to hydrocarbons, but also because ETICs provide the necessary structural trap needed for localizing mineral rocks and holding mobile liquids, which may include oil [7].

Silali basin and the surrounding area had some iron, gold, copper and nickel. Petroleum deposits will not be expected in the Silali basin because of the high temperatures [7].

Laboratory tests were carried out on the Kimwiri meteorite, Chemolingot rock and solid rock samples from the Silali basin. The tests were analysed at the Department of Mines and Geology, Nairobi, Kenya and the results are as shown in Figure 7 [7]. 
Figure 7: A comparative bar graph of the chemical composition of the rocks sampled [7]

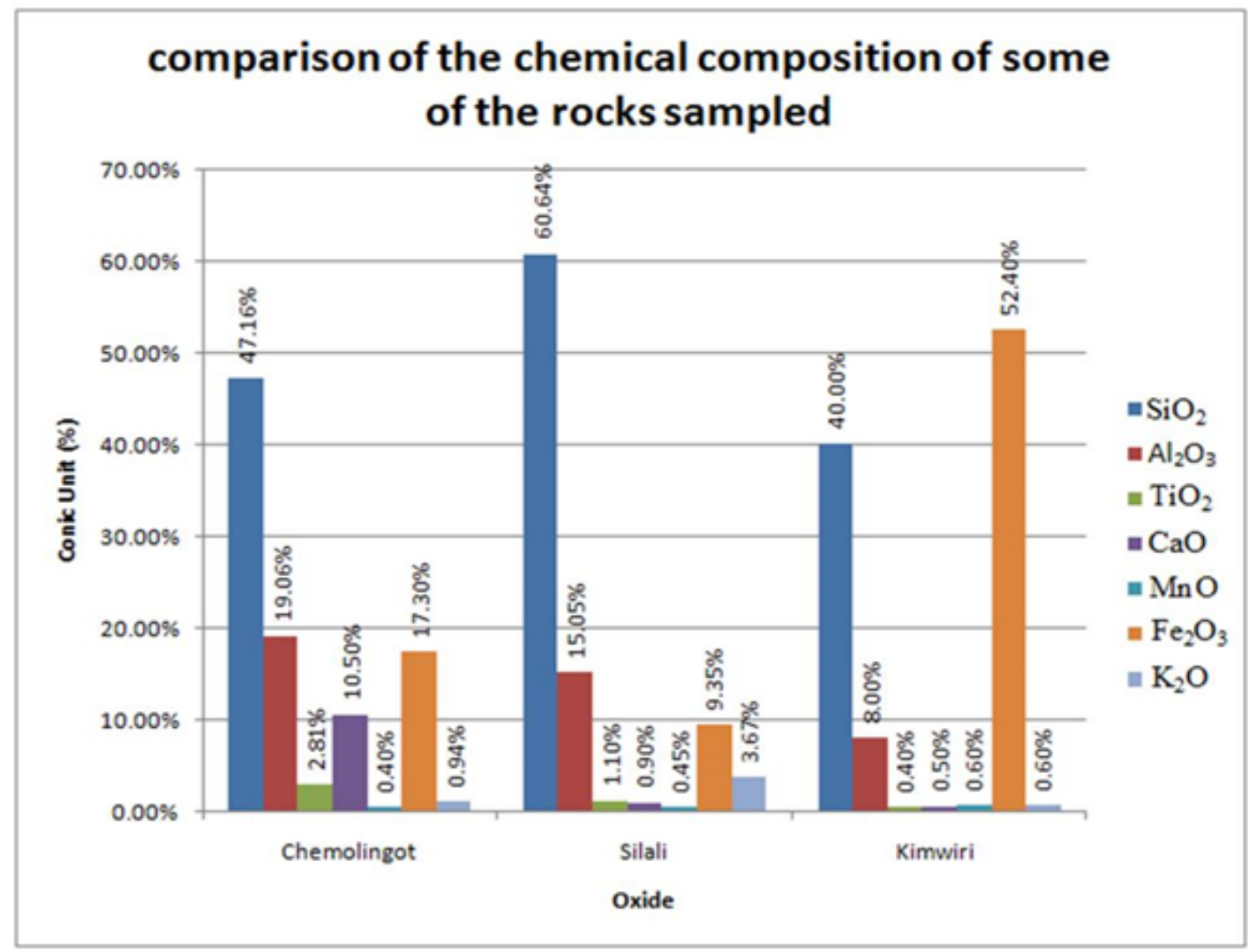

From Figure 7, the Kimwiri meteorite, the Chemolingot rock and the rocks from the Silali basin share certain characteristics that include all the three rocks having similar chemical elements, among the sampled ETIC related oxides, though in varying percentages.

\section{Planar Deformation Features (PDFs)}

Tests were carried out to ascertain the presence of PDFs in the basin. Some of the results show what appears to be PDFs, as depicted in Table 1 and Figure 8. The samples that were tested were collected from the basin's floor. However, the samples were few and cannot be taken summarily.

Table 1: Shows the results of a Petri-graphic study of a rock sample from Silali basin, courtesy of the Department of Mines and Geology, 2015 [7]

\begin{tabular}{|l|l|}
\hline \multicolumn{2}{|c|}{ Petrographic study in thin section } \\
\hline Major constituents (\%) & $\begin{array}{l}\text { Cryptocrystalline pyroxenes }-50 \% \\
\text { Quartz } 35 \% \\
\text { Opaque }-10 \% \\
\text { Others - 5\% }\end{array}$ \\
\hline Accessory (\% or trace) & - \\
\hline Secondary (\% or trace) & - \\
\hline Lithology & The rock is interpreted as volcanic trachyte \\
\hline Petrographic descriptions & \\
\hline $\begin{array}{l}\text { Quartz (35\%), Cryptocrystalline pyroxenes }-50 \% \text { and other minerals. Individual grains of quartz are } \\
\text { fractured. }\end{array}$ \\
\hline
\end{tabular}


Figure 8: A thin section of one of Silali basin's sampled rocks, courtesy of the Department of Mines and Geology, 2015 [7]

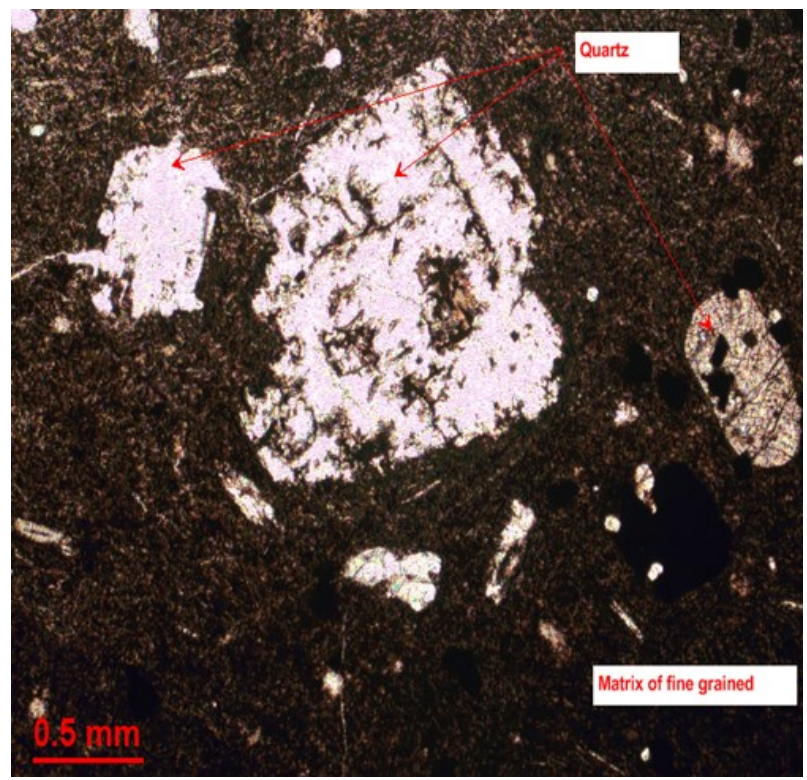

PDFs are the ultimate signature of an ETIC.

\section{Evidence of the 'Outer Basin' and its Features}

The 'outer basin' and some features which were observed in it, may support an impact formation of the outer basin and the Silali basin as well. These features include the slumped walls of the outer basin, breccias, shatter cones and a unique rock that looks like a magma pillow [7].

A magma pillow is a pillow-shaped lava structure that is attributed to the extrusion of lava underwater (subaqueous extrusion). It is commonly basaltic in nature and the more viscous the lava, the bigger the pillow. Magma pillows are common along marine volcanic hot spots and constructive plate boundaries (tensional boundaries). Due to the rapid cooling of the magma as it touches water, the magma's outer layer forms its outer coat or shell. Subsequent shells are formed as the magma cools towards its core. Thus, magma pillows are layered. The outer layers are made up of finer particles, owing to fast cooling, while the core is made up of coarse grains. The outer layer of a magma pillow is mainly glassy [7].

The unique rock, here known as the Chemolingot rock, the Chemolingot shatter cones, together with the slumped walls of the outer basin, are evidence that the 'outer basin' may also be an ETIC. Plates 9 and 10 show the Chemolingot rock and Chemolingot shatter cones, respectively. Chemolingot area is to the south of Silali basin, near Chemolingot town on the outer basin. Since shatter cones only form inside an impact crater, their presence in Chemolingot is a likely suggestion that the Chemolingot area is an extra-terrestrial impact area. Chemolingot is on the outer basin. Consequently, the outer basin could be a product of an extra-terrestrial impact. More research on the outer basin can be carried out in the future [7].

Plate 9: A picture showing a unique rock (Chemolingot rock) collected from the Chemolingot area, in East Pokot. A brown coated probable chondrule is pointed [7]

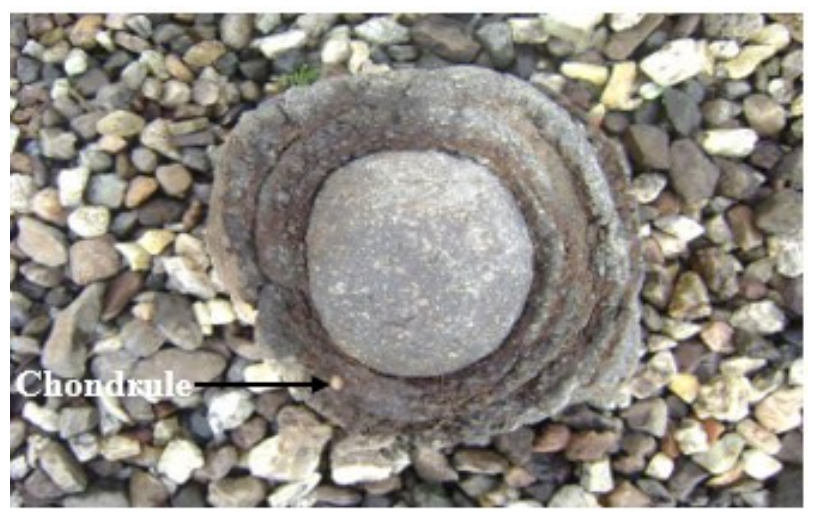

Plate 10: A picture showing shatter cones (SC)around the Chemolingot area of East Pokot [7]

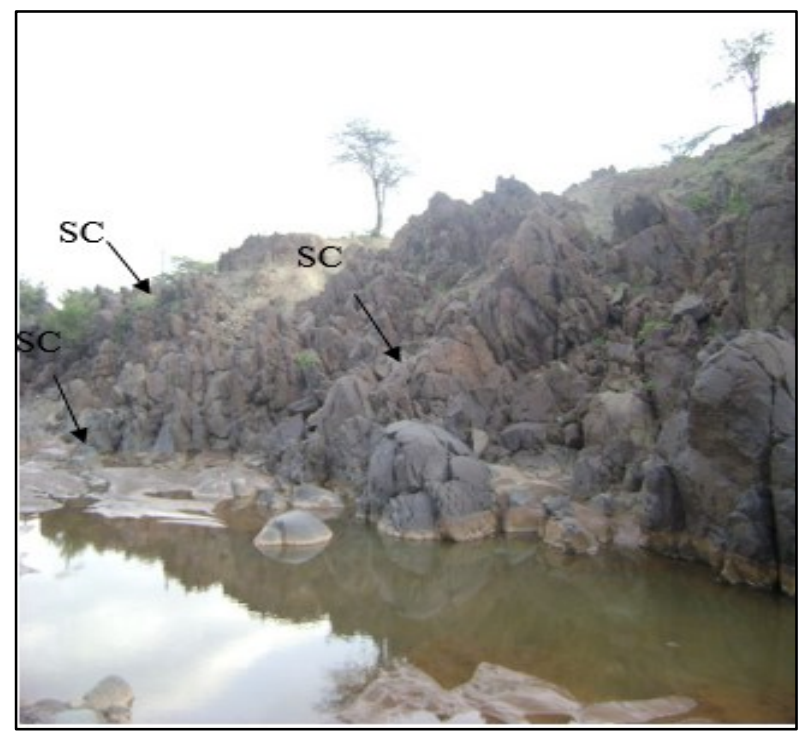


The slumped walls (Plate 11) of the outer basin are the materials that fell back to infill the basin after a possible impact. Photographs of the slumped walls were acquired at different parts of the outer basin, especially to the south and west of Silali basin, which is accessible [7].

Plate 11: A picture showing another section of the slumped walls of the outer basin; to the southwest of Silali basin [7]

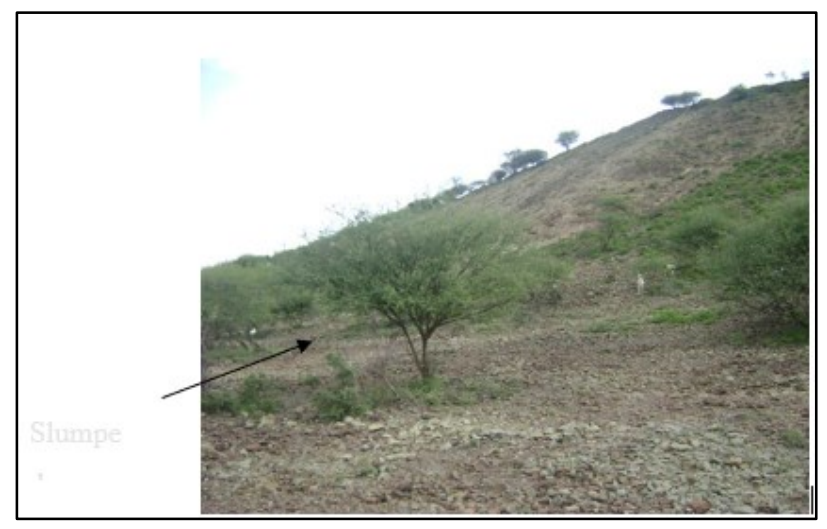

\section{CONCLUSION}

Besides the basin's ETIC morphological characteristics, the Silali basin has many other ETIC characteristics that include the basin's ETIC related geology and rock chemistry, the basin's geophysics and the many geomorphological features that are associated with the basin. In conclusion, the Silali basin seems to have formed, as an ETIC, not only on an area of volcanic rock but on a volcanic shield, through an extra-terrestrial impact and later, subsidence. The basin also bears the morphological classic hallmarks of an impact crater, which include slumped walls inside the rim, rough irregular crater floor, stepped walls, a circular morphology, and hummocky deposits (ejecta) outside the basin.

Thus, the Silali basin is an ETIC that is rich in volcanic features. Old and recent volcanicity has created many volcanic features in the basin to an extent that the basin can easily pass for a volcano. However, the Silali crater cannot be considered a volcano because it is not found atop a volcanic edifice the way summit craters are found at the top of volcanic cones, such as the nearby Mt. Paka. The lack of a cone shape in the raised area surrounding the basin is clearly visible in the images and figures presented. The ETIC geology of Silali basin can be assessed for tourism, decoration, and mining possibilities.

\section{REFERENCES}

[1] Beatty, J. K., Peterson, C. C. and Chaikin, A. (1999): The New Solar System, $4^{\text {th }}$ edition, Sky Publishing, Massachusetts.

[2] Dunkley, P. N., Smith, M., Allen, D. J. and Darling, W. G. (1993): Geothermal Activity of the Northern Sector of the Kenya Rift Valley, British Geological Survey, Keyworth, Nottingham.

[3] GoK. (2009): Arid Lands Resource Management Project; Mineral Exploration and Assessment of Geological Materials and Geoourism Sites in ALRMP Area, Baringo and East Pokot Districts, Ministry of Environment and Natural Resources, Nairobi.

[4] Hackman B. D. 1988. Geology of the Baringo - Laikipia area. Report No. 104. Geological Survey of Kenya.

[5] Heller, M. A. and Eisenberg, R.S. (1998): Tragedy of the Anticommons, Science, May 1; 280(5364):698-701.

[6] http://en.wikipedia.org/wiki/volcanic_ash

[7] Kipkiror, L. J. (2016). Identification of an Extra-Terrestrial Impact Crater: A Case Study of Silali Crater, Kenya. University of Eldoret.

[8] Kipkiror, L. J. (2018): The formation of Silali Basin as a Complex Extra-Terrestrial Impact Crater (ETIC): International Journal of Geology and Earth Sciences (IJGES, 2018).

[9] Kipkiror, L. J. (2018): Extra-Terrestrial Impact Craters (ETICS) and Related Geomorphology- A Case Study of Silali Basin, Kenya, Global Journal of Human-Social Science: Geography, Geosciences, Environmental Science \& Disaster Management. 19(2), 1-24. ISSN 2249-460X and ISSN 0975-587X.

[10] Kipkiror, L. (2016): The Morphological Characteristics of Silali Basin as an Extraterrestrial Impact Crater (ETIC), Proceedings 
of the University of Kabianga First International Conference, $26^{\text {th }}-28^{\text {th }}$ October 2016.

[11] Kipkiror (2018): The Importance of Silali Basin (Kenya) as an Extra-Terrestrial Impact Crater (ETIC), University of Kabianga, $2^{\text {nd }}$ International Conference, $9^{\text {th }}-10^{\text {th }}$ May 2018.

[12] Kipkiror, L., Ucakuwun, E. and Daudi. F. (2016): Effects of Silali Basin' Impact Cratering on the Environment of the area, Elixir International Journal (ISSN 2229712X).

[13] Kipkiror, L., Ucakuwun, E. and Daudi. F. (2016): Investigation of Silali Basin as an Extra-terrestrial Impact Crater (ETIC) Using Remote Sensing, Journal of Environment and Earth Science (ISSN 2224-3216).

[14] Lichoro, C. M. (2013): Multidimensional Interpretation of Electromagnetic Data from Silali Geothermal field in Kenya: Comparison between 1-D, 2-D and 3-D MT Inversion, University of Iceland.

[15] McCall, G. J. H., \& Hornung, G. (1972). A geochemical study of Silali volcano, Kenya, with special reference to the origin of the intermediate-acid eruptives of the Central Rift Valley. In Developments in Geotectonics (Vol. 7, pp. 97-113). Elsevier.

[16] Nelson, S. A. (2015). Magma and Igneous Rocks: Lecture notes, Tulane University, New Orleans, LA 70118, USA. http://www.tulane.e $\mathrm{du} / \sim$ sanelson/eens1110/igneous.htm

[17] Rop, B. K. and Namwiba W.H. (2019): Applied Geology in Construction Practice: A Companion for infrastructural development 692p. Verlag/Publisher: Scholar's Press ISBN 978-613-8-83476-2.

[18] Rop, B. K. (2013): Oil and Gas Prospectively: Northwestern Kenya (Revised Eds.), 153 p. Verlag/Publisher: LAP LAMBERT Academic Publishing ISBN 978-3-659-49008-8

[19] Smith, M., Dunkley, P. N., Deino, A., William, L. A. J. and McCall, G. J. H. (1995): Geochronology, Stratigraphy and Structural
Evolution of Silali Volcano, Gregory Rift, Kenya, British Geological Survey, Edinburgh, UK.

[20] Therriault, A. M., Grieve, R. A. F. and Pillington, M. (2002): The Recognition of Terrestrial Impact Structures, Bulletin of the Czech Geological Survey, vol. 77, no 4, 253263

[21] Tsikalas, F., Gudlaugsson, S. T., Faleide, J. I. and Eldholm, O. (1998): The Anatomy of a Buried Complex Impact Structure. The Mjolnir Structure, Barents Sea, Geophysics Journal, 103, 30, 469-30, 483.

[22] Loice K., (2018): Extra-Terrestrial Impact Craters (ETICs) and Related GeomorphologyA Case Study of Silali Basin, Kenya. Global Journal of Human-Social Science: Geography, Geo-Sciences, Environmental Science \& Disaster Management, 19(2), 1 - 24. ISSN 2249-460X and ISSN 0975-587X.

[23] Williams, L. A. J., MacDonald, R. and Chapman, G.R. (1984): Late Quaternary Caldera Volcanoes of the Kenya Rift, Journal of Geophysical Research, 89, B10, 8553-8570.

[24] www.solarviews.com

[25] www.sciencemag.org.

[26] Traver, G.A. (2007): Dynamics and Structural Evolution of Collapse of Calderas: A Comparison between Field Evidence, Analogue and Mathematical Models, University of Barcelona, Barcelona. 